\title{
A imagem do outro na Crónica da Tomada de Ceuta pelo Rei D. João I de Gomes Eanes de Zurara
}

The image of the Other in Gomes Eanes de Zurara's Crónica da Tomada de Ceuta pelo Rei D. João I

\section{Natália Albino Pires}

\section{OpenEdition}

\section{Journals}

Edição electrónica

URL: http://journals.openedition.org/medievalista/1213

DOI: 10.4000/medievalista.1213

ISSN: 1646-740X

\section{Editora}

Instituto de Estudos Medievais - FCSH-UNL

\section{Refêrencia eletrónica}

Natália Albino Pires, «A imagem do outro na Crónica da Tomada de Ceuta pelo Rei D. João I de Gomes Eanes de Zurara », Medievalista [Online], 20 | 2016, posto online no dia 01 junho 2015, consultado no dia 04 maio 2019. URL : http://journals.openedition.org/medievalista/1213; DOI : 10.4000/ medievalista. 1213

(C) IEM 
Título / Title: A imagem do outro na Crónica da Tomada de Ceuta pelo Rei D. João I de Gomes Eanes de Zurara / The image of the Other in Gomes Eanes de Zurara's Crónica da Tomada de Ceuta pelo Rei D. João I

Autor(es) / Author(s): Natália Albino Pires

Universidade / University: Instituto Politécnico de Coimbra

Faculdade e Departamento / Unidade de Investigação - Faculty and Department /

Research Center: Escola Superior de Educação de Coimbra / Instituto de Estudos de Literarura e Tradição (FCSH/NOVA)

Código Postal / Postcode: 3030-329

Cidade / City: Coimbra

País / Country: Portugal

Email: npires@esec.pt

Fonte: Medievalista [Em linha]. Direc. Bernardo Vasconcelos e Sousa. Lisboa: IEM.

Disponível em:

http://www2.fcsh.unl.pt/iem/medievalista/MEDIEVALISTA20/pires2007.html ISSN: 1646-740X

Data recepção do artigo / Received for publication: 16 de Março de 2015

Data aceitação do artigo / Accepted in revised form: 20 de Maio de 2016 


\section{Resumo}

A representação do outro é tão antiga como a história cultural da humanidade e a imagem que desse outro se veicula depende integralmente do eu que a descreve e constrói. Assim, tendo por base os pressupostos teóricos da imagologia, propomo-nos analisar a imagem do mouro transmitida na Crónica da Tomada de Ceuta, procurando rastrear o topos do enaltecimento dos portugueses, basilar da construção da identidade nacional.

Palavras-chave: Mouro, Portugueses, alteridade, Crónica da Tomada de Ceuta, Zurara.

\section{Abstract}

The representation of the Other is as old as the cultural history of humanity and the image that is portrayed of that Other depends entirely on the I that describes and builds it. Thus, based on the theoretical assumptions of imagology, we aim at analysing the image of the moors as depicted on the Chronicle of the Conquest of Ceuta, seeking to track the topos of the Portuguese praise, cornerstone of the construction of national identity.

Keywords: Moor, Portuguese, Otherness, Crónica da Tomada de Ceuta, Zurara 


\section{A imagem do outro na Crónica da Tomada de Ceuta pelo Rei D. João I de Gomes Eanes de Zurara / The image of the Other in Gomes Eanes de Zurara's Crónica da Tomada de Ceuta pelo Rei D. João I}

Natália Albino Pires

\section{Introdução}

A imagem do outro depende integralmente do "eu" que a descreve e que a constrói e é uma temática tão antiga como a história da humanidade. Das primeiras imagens icónicas do outro nas pinturas rupestres ou na arte paleolítica à imagem do outro no texto literário ao longo dos milénios, evidencia-se um longo processo (re)construtivo. As descrições do outro, ao longo da história cultural da Humanidade, vão, com todas as dificuldades definitórias subjacentes a estes adjectivos, do grotesco ao belo e estão presentes em diversos âmbitos desde o literário ao filosófico (ao sociológico ou antropológico) da antiguidade até ao presente.

Do ponto de vista cultural, a noção do outro tem sido quase sempre construída a partir da perspectiva do ocidental, quer estejamos a reportar-nos a textos da antiguidade clássica ou do século XX, sendo de destacar as descrições do outro que se julgava existirem nos territórios inabitados para lá do mundo conhecido ${ }^{1}$; as risíveis descrições do outro patentes na literatura de viagens, tanto portuguesa como espanhola, inerentes à

\footnotetext{
${ }^{1}$ DIAS, Isabel Barros - "A migração dos portentos". in VV.AA. - Revisitar o Mito / Myths Revisited. Lisboa: Húmus, 2015, pp. 749-762.
} 
descoberta do Novo Mundo ${ }^{2}$ e, ainda, as teorizações iluministas francesas sobre o outro, em especial a teoria do "bom selvagem", que contribuíram para evitar por algum tempo a escravatura dos índios no Brasil. Por outras palavras e pese embora a personagem referir-se às diferenças sociais entre homens e mulheres, a perspectivação do outro e a sua descrição são feitas "por aquele que possui o poder da escrita" tal como lembra a burguesa de Bath na obra de Chaucer $^{3}$ ou tal como lembra o próprio Zurara a propósito da memória histórica na obra que ora analisamos:

"E quall he mais segura sepulltura pera quallquer primçipe ou baram uirtuoso, que a escpritura que rrepresemta o claro conheçimento de suas obras passadas. Certo toda a nobreza dos homeẽs fora destroida, sse as penas dos escpriuaães a nom poseram em fim"4.

Na Literatura, o percurso da construção da imagem do outro seria impossível de descrever no âmbito de um breve estudo porquanto se trata de um topos desenvolvido ao largo de séculos e, exactamente pelos mesmos motivos, também será inexequível traçar a sua presença no âmbito restrito de uma qualquer cultura particular.

Assim, tendo em conta o seu contexto de redacção, as peculiaridades literárias e culturais subjacentes às primeiras crónicas da segunda dinastia e as relações mouro/cristão durante os séculos XV e XVI, procuraremos analisar a imagem do outro, particularmente, a imagem do mouro ${ }^{5}$ veiculada na Crónica da Tomada de Ceuta, de Gomes Eanes de Zurara.

\footnotetext{
${ }^{2}$ Lembramos, a título de exemplo, a Carta de Achamento do Brasil, de Pero Vaz de Caminha, a Notícia do Brasil, de Gabriel Soares de Sousa, o texto de Cristóvão Colombo sobre as Antilhas ou a Brevísima Relación de la Destrucción de las Indias de Bartolomé de las Casas.

${ }^{3}$ Apud ANDRADE FILHO, Ruy de Oliveira; CARVALHO, Ligia Cristina - "Medieval Misogyny and its echoes in the Lais of Marie de France". Mirabilia, Bd. 17, p. 469. Não obstante, ao olhar ocidental, faltalhe descortinar a imagem que aquele que ele considera outro tem sobre si. Nesta medida, faltam efectivamente estudos comparativos inter e multiculturais que permitam contrastar a imagem que nós temos do outro com a que a outro tem de nós, quer nos reportemos à relação mouro/cristão; branco/negro; europeu/ameríndio ou ocidental/oriental.

${ }^{4}$ ZURARA, Gomes Eanes de - Crónica da Tomada de Ceuta por el Rei D. João I composta por Gomes Eanes de Zurara. Ed. Francisco Maria Esteves Pereira. Lisboa: Academia das Ciências de Lisboa, 1915, p. 273.

${ }^{5}$ Ao longo desta Crónica vão surgindo várias personagens forâneas ao reino e, embora as suas descrição e caracterização pareçam depender da sua origem/ procedência, subentende-se nas palavras do cronista um tratamento menos valoroso para com os forâneos, como é o caso dos embaixadores espanhóis que vêm assinar as pazes.
} 


\subsection{Contexto de redacção da Crónica da Tomada de Ceuta}

Nascido entre 1410 e 1420, Gomes Eanes de Zurara é, na história da cronística portuguesa, o segundo cronista mor do Reino e substitui Fernão Lopes no ofício de guarda das escrituras da Torre do Tombo em 1454. Por encargo de D. Afonso V, escreve a Crónica da Tomada de Ceuta por el Rei D. João I; a Crónica dos Feitos da Guiné; a Crónica do Conde D. Pedro de Meneses e, finalmente, a Crónica do Conde D. Duarte de Meneses.

Sem pretensão de aprofundar questões relativas ao contexto social, político e cultural da época em que a Crónica que analisamos foi escrita, importa, porém, ter presentes as palavras de Bertoli $^{6}$ ou de Michelan ${ }^{7}$. Com efeito, Bertoli ${ }^{8}$ lembra que "as obras de Zurara fazem parte de um projecto de escrita para legitimar o poder régio e de parte da nobreza, bem como justificar suas ações. Este projecto está explícito nas três crônicas marroquinas que, por vezes, têm extensões de textos em comum". E Michelan reforça as suas palavras ao afirmar que:

"o papel das crônicas, produzidas sob a égide da dinastia de Avis, foi, fundamentalmente, de lançar as bases para a construção de uma imagem dinástica a ser fixada e transmitida para a posteridade, a partir, em grande parte, da exaltação política de tal dinastia, em que as figuras passadas serviam de alicerce para sustentar as ações presentes, além de criarem a ideia de continuidade política, mesmo com a mudança dinástica"9.

Antes de entrarmos na análise da imagem do mouro veiculada na Crónica da Tomada de Ceuta, parece-nos, também, relevante recordar que, à época da conquista de Ceuta, e até bem tarde na história moderna europeia, a guerra contra os mouros foi considerada justa e santa, procurando-se recuperar as antigas terras da cristandade (nomeadamente

\footnotetext{
${ }^{6}$ BERTOLI, André Luís - "Modelos de acção bélica na Crónica de D. Duarte de Meneses. Texto, contexto e representação". Mirabilia [Em linha]. N. 15 (2012), pp. 171-201. [Consultado em 20 Jan. 2015]. Disponível em http://www.revistamirabilia.com/sites/default/files/pdfs/2012_02_09.pdf

${ }^{7}$ MICHELAN, Kátia Brasilino - Ceuta, para além da terra dos Mouros. A fabricação histórica de um marco do império português (Século XV e início do XVI). Franca: Faculdade de Ciências Humanas e Sociais da Universidade Estadual Paulista Júlio de Mesquita Filho, 2013. Tese de Doutoramento.

${ }^{8}$ BERTOLI, André Luís - "Modelos de acção bélica"..., pp. 181-182.

${ }^{9}$ MICHELAN, Kátia Brasilino - Ceuta, para além da terra..., pp. 153-154.
} 
aquelas que haviam pertencido aos visigodos de quem os reis ibéricos se consideravam descendentes directos) e ancorando-se todos os actos de conquista nos baluartes teológicos da Igreja católica, isto é, na teorização de Santo Agostinho e na de São Tomás de Aquino. Nesta medida e tal como lembra Michelan, as diferentes crónicas retomam sucessivamente tópicos utilizados pelos antecessores, nomeadamente:

\begin{abstract}
"a história como mestra da vida, a referência e/ou a analogia às personagens antigas e bíblicas, a defesa do combate aos cismáticos e sarracenos, as menções às profecias, a constante referência à intervenção da providência divina, a ênfase sobre a lamentação dos mouros após as vitórias cristãs e a narrativa centrada nos monarcas"10.
\end{abstract}

De facto, e tal como lembram diversos autores a propósito de outros textos cronísticos ibéricos ${ }^{11}$, todos estes tópicos, em particular o tópico da guerra santa, estão patentes nas Crónicas que descrevem a progressão da (re)conquista cristã a partir do episódio dos mártires de Córdova ${ }^{12}$.

\title{
1.2. A imagem do outro
}

O estudo das representações do outro tem-se desenvolvido sob a égide da imagologia, cujo objectivo principal "es el de revelar el valor ideológico y político que puedan tener ciertos aspectos de una obra literaria precisamente porque en ellos se condensan las ideas que un autor comparte con el medio social y cultural en que vive"13. Por conseguinte, a imagologia "studies the origin and function of characteristics of other

\footnotetext{
${ }^{10}$ MICHELAN, Kátia Brasilino - Ceuta, para além da terra..., pp. 166-167.

${ }^{11}$ DIAS, Isabel Rosa - "O mouro na Crónica da Conquista do Algarve". in AMADO, Teresa - A guerra antes de 1450. Lisboa: Quimera, 1994, pp. 365-376; FIGUEIREDO, Fernando - "Da imagem do inimigo à construção do herói. O reinado de Afonso Henriques na Crónica dos Cinco Reis de Portugal". in AMADO, Teresa - A guerra antes de 1450. Lisboa: Quimera, 1994, pp. 377-390; GIMÉNEZ, José Carlos - "As representações dos muçulmanos durante a tomada de Lisboa pelos cristãos". Revista Diálogos Mediterrânicos [Em linha]. N. 7 (2014), pp. 53-65. [Consultado em 5 Jun. 2015]. Disponível em http://www.dialogosmediterranicos.com.br/index.php/RevistaDM/issue/view/13/showToc

12 KRUS, Luís - "Tempo de godos e tempo de mouros: as memórias da reconquista". in KRUS, Luís - A construção do passado medieval. Textos inéditos e publicados. Lisboa: IEM, 2011, pp. 93-113.

${ }^{13}$ MOLL, Nora - "Imágenes del outro". in GNISCI, Armando - Introdución a la literatura comparada. Barcelona: Crítica, 2002, p. 349.
} 
countries and people, as expressed textually, particularly in the way in which they are presented in works of literature, plays, poems, travel books and essays"14.

Com efeito, a cronística de Zurara, ainda que estudada maioritariamente como fonte da faceta expansionista portuguesa ${ }^{15}$, faculta-nos um conjunto de constructos imagísticos ora baseado nas "representações tradicionais do outro vigentes no imaginário colectivo da época, [ora] resultantes de uma amálgama não muito bem definida de memórias orais dos tempos da Reconquista"16. Nesta sequência, Blackmore considera que nas crónicas de Zurara "the mouro responds to different textual and political exigencies and is refashioned according to the incipient culture of imperial textuality" ${ }^{17}$ e afirma que tanto a Crónica da Tomada de Ceuta como a Crónica da Guiné marcam "a transition between representations of the Moor as the Arabic-speaking Muslim familiar to Iberian history as a new and strange occupant of unexplored regions of Africa" ${ }^{18}$.

A imagem do mouro e as relações Mouro/Cristão têm sido particularmente evidenciadas nas crónicas dos Menezes, destacando-se as parcas referências à imagem do mouro veiculadas na Crónica da Tomada de Ceuta ${ }^{19}$. Centraremos, por isso, a nossa atenção exclusivamente nesta Crónica e procederemos ao levantamento e análise da imagem do mouro enquanto outro nela veiculada, subjazendo, à nossa proposta analítica, os

14 BELLER, Manfred; LEERSSEN, Joep - Imagology: the cultural construction and literary representation of national characters. Amesterdam / New York: Rodopi, 2007, p. 7.

15 BRAGA, Isabel M. Ribeiro Mendes - "As relações Mouros / Cristãos nas Crónicas marroquinas de Gomes Eanes de Zurara". Eborensia, n. 19/20 (1997), pp. 171-180.

${ }^{16}$ LOUREIRO, Rui Manuel; CARDOSO, João Passos; CABRITA, Maria da Graça - "Visão do mouro nas Crónicas de Zurara". in Caderno Histórico IV. Actas do Seminário "Os Descobrimentos Portugueses e o Algarve d'Aquém e d'Além-Mar". Lagos: Comissão Municipal dos Descobrimentos, 1993, p. 61.

${ }^{17}$ BLACKMORE, Josiah - "Imaging de Moor in Medieval Portugal". Diacritics, vol. 36, n. 3/4, 2006, p. 32.

${ }^{18}$ BLACKMORE, Josiah - "Imaging de Moor"..., p. 32.

${ }^{19}$ Para a imagem do mouro veiculada na cronística de Zurara, salientamos LOUREIRO, Rui Manuel et alii. - "Visão do mouro"...; BRAGA, Isabel M. Ribeiro Mendes - "As relações Mouros / Cristãos"...; BOISVERT, Georges - "La dénomination de l'Autre africain au XV siècle dans les récits des découvertes portugaises". L'Homme [Em linha]. N. 153 (2000), pp. 165-169. [Consultado em 30 Set. 2014]. Disponível em http://lhomme.revues.org/10; BLACKMORE, Josiah - "Imaging de Moor"...; CARDOSO, Sylnier Moraes - "A oposição mouro-cristão na narrativa de Gomes Eanes de Zurara". in Anais do I Congresso Nacional e II Regional de História da UFG [Em linha]. Jataí, 2008, pp. 1-12. [Consultado em 16 Out. 2014].Disponível em http://www.congressohistoriajatai.org/2014/anais2008.htm; GUIMARÃES, Jerry Santos - "Memória e retórica: mouros e negros na Crónica da Guiné (século XV)". in Anais do XXVI Simpósio Nacional de História - ANPUH [Em linha]. São Paulo, 2011, pp. 1-16. [Consultado em 25 Jun. 2014]. Disponível em http://www.snh2011.anpuh.org/resources/anais/14/1308163586_ARQUIVO_MemoriaeRetoricaMouroseNegrosnaCronicadeGuine\%28SeculoXV\%29.pdf 
pressupostos teóricos da imagologia e, também, as definições do "eu" e do "outro" propostas por Todorov ${ }^{20}$.

\title{
A imagem do mouro na Crónica da Tomada de Ceuta
}

O cronista, ao longo da obra, valida reiteradamente as suas afirmações com a filosofia aristotélica, com as bases teológicas da Igreja Católica (sobretudo Santo Agostinho e São Tomás de Aquino) e com citações dos Evangelhos (de S. Lucas, de S. Mateus e de S. João), afirmando, desde o capítulo primeiro, que há povos eleitos de Deus a quem Este ajuda a cumprir os seus desideratos. Nesta medida, o cronista expressa, desde as primeiras linhas da obra, a grandeza de carácter e a absoluta devoção religiosa do rei D. João I e centra-se na descrição dos seus feitos e acções num período de tempo específico (desde o surgimento e maturação da ideia de conquistar a cidade de Ceuta ao momento em que a empresa da sua tomada se dá por terminada), dando com este texto continuidade às duas primeiras partes da crónica deste rei escritas por Fernão Lopes.

Cumprindo uma especificidade discursiva da cronística medieval e à semelhança do seu antecessor, Fernão Lopes ${ }^{21}$, o cronista adverte para o poder da oração e da invocação dos Santos, em especial da Virgem Santa Maria, como intermediários entre Deus e o Homem para a outorga de graças. Consequentemente, ele próprio, deixando patente a sua "rrudeza e fraco engenho"22, invoca num largo trecho a inspiração necessária para a escrita dos feitos do rei D. João I e reconhece que sem essa intervenção divina não será capaz de tal empresa:

\begin{abstract}
"digo com toda humildade e rreverencia em aquesta guisa. Aquelle cuja graça per diuinal rresplendor enframou os corações dos seus santos apostolos da perfeita sabedoria com espritual eloquençia. mande sobre mim alguũa parte dos atomos daquella graça. que per minha rrudeza e
\end{abstract}

\footnotetext{
20 TODOROV, Tzvetan - Nous et les autres. Paris: Seuil, 1989.

${ }^{21}$ Vários autores mostram os paralelismos discursivos, do ponto de vista da construção da diegese, entre a Crónica de D. João I de Fernão Lopes e a Crónica da Tomada de Ceuta de Zurara (Cf. MICHELAN, Kátia Brasilino - Ceuta, para além da terra...; BERTOLI, André Luís - "Modelos de acção bélica..."; CARDOSO, Sylnier Moraes - "A oposição mouro-cristão"...).

22 ZURARA, Gomes Eanes de - Crónica da Tomada de Ceuta..., p. 7.
} 
fraco engenho possa falar da franqueza e marauilhosos feitos deste virtuoso e nunqua vençido prinçipe senhor Rey Dom Joham [...] conheçendo que per mim nenhuũa cousa posso sem sua graça e ajuda"23.

A primeira referência à "tam nobre e tam grande çidade como he Cepta", forçosamente conquistada por armas e ao serviço de Deus, surge logo no capítulo segundo e, neste mesmo capítulo, o cronista introduz-nos a lenda, reiteradamente veiculada por fontes escritas anteriores $^{24}$, da traição de D. Julião que, por vingança para com o rei D. Rodrigo, entrega a cidade aos mouros ${ }^{25}$. A seguinte descrição da cidade ocorre no capítulo nono e é posta na boca de Joham Affonso, vedor da fazenda, que dela fala aos Infantes, arrazoando-lhes os intentos de se tornarem cavaleiros na sequência de um feito valoroso, próprio da sua condição nobre excepcional:

\begin{abstract}
"Vossos pensamentos disse elle sam assaz de grandes e boõs. e pois que vos taal vontade tendes eu vos posso assinar huũa cousa em que o podees bem e honrradamente executar. E esto he a çidade de Cepta que he em terra dAffrica que he huũa muy notauel çidade e muy azada pera se tomar. e esto sey eu principalmente per hum meu criado que la mandey tirar alguũs catiuos de que tinha encarrego. ele me contou como he huũa muy grande çidade rriqua e muy fermosa. e como de todallas partes a çerqua o mar afora huũa muy pequena parte por que am sayda pera a terra" 26 .
\end{abstract}

A primeira caracterização do mouro surge conjuntamente com a primeira referência a Ceuta. Numa prolepse, o cronista afirma: "Eras tu primeiramente de naçam barbara mais baxa de todallas nações", estando, agora, afastadas da cidade "as ençuguentadas

\footnotetext{
${ }^{23}$ ZURARA, Gomes Eanes de - Crónica da Tomada de Ceuta..., pp. 7 e 8.

${ }^{24}$ Embora o cronista valide a sua versão da lenda com a referência a Abilabez, a $\mathrm{St}^{\circ}$ Isidro, mestre Pedro e D. Lucas de Tuy, trata-se de uma lenda que foi sendo refeita e reutilizada em diversos textos portugueses, castelhanos e árabes (Cf. GONZALBES GRAVIOTO, Enrique - "El comes Iulianos (Conde Julián de Ceuta) entre la historia y la literatura". Al Quantir [Em linha]. N. 11 (2011), pp. 3-35. [Consultado em 4 Abr. 2016]. Disponível em http://s17809026.onlinehome-server.info/ojs-2.4.4-1/index.php/alqantir/article/view/185/154; Cf. idem "El paso del estrecho: las fuentes". Aljaranda [Em linha]. N. 81 (2011b), pp. 37-42. [Consultado em 4 Abr. 2016]. Disponível em http://www.aljaranda.com/index.php/aljaranda/article/view/142

${ }^{25}$ ZURARA, Gomes Eanes de - Crónica da Tomada de Ceuta..., p. 10.

${ }^{26}$ Ibidem, p. 27.
} 
çerimonias do abominauel Mafamede"27. Ao longo da obra, as referências ao mouro, quer se trate do mouro forro, do mouro granadino ou do habitante de Ceuta, ocorrem em momentos chave da narração, denotando um objectivo discursivo por parte do cronista. Enquanto a ledice dos portugueses contrasta com a tristeza dos habitantes de Ceuta, a imagem ambígua que o cronista veicula do mouro amplifica a caracterização dos portugueses como corajosos e valerosos homens, mas mostra também que a tomada de Ceuta fora predestinada e, por conseguinte, os mouros nada poderiam ter feito para a manter em seu poder.

\subsection{O mouro: do infiel ao traidor}

Em geral, as macro-referências ao mouro adjectivam-no sempre como infiel e bárbaro. Embora nem sempre estas referências sejam pejorativas, atestamos diversos momentos em que o mouro nos é apresentado como ignóbil. Do encontro da embaixada granadina com a rainha, o cronista assevera que, sendo esta uma mulher "muito amiga de Deus" e originária de Inglaterra, "cuja naçam amtre as do mumdo naturallmente desamam todollos jmfiees", muito dificilmente aceitaria favores de um infiel ${ }^{28}$. Com efeito, os seguidores do "abominável Mafamede", isto é, os infiéis surgem quase sempre por oposição à devoção religiosa dos portugueses: os primeiros serão castigados por não terem escolhido a verdadeira Fé e os segundos agraciados com vitórias, dada a sua Fé verdadeira.

Imediatamente antes da entrada dos portugueses em Ceuta, alguns velhos dirigem-se às mesquitas e fervorosamente tecem preces ao profeta Mafamede para que não os abandone $^{29}$. Concomitantemente, Martim Paaez, o capelão do Infante D. Henrique, que no capítulo septuagésimo primeiro incita os homens a um fervoroso serviço de Deus, refere-se aos seguidores de Mafamede como má semente que deve ser arrancada pelos fiéis porquanto em breve aquela "amortificaria toda a boõa semente" ${ }^{30}$.

\footnotetext{
${ }^{27}$ Ibidem, pp. 10-11.

${ }^{28}$ Ibidem, p. 107.

${ }^{29}$ Ibidem, Cap. LXVIII.

30 "aquelle emçugemtado e abominauell çismatico Mafamede, tomou falsso nome de profeta, sob collor de uirtude e onestidade semeou pollo mundo esta sua danada seyta. a quall assy como as maas heruas ham natureza de creçer mujto mais, que as proueytosas e boõas. bem assy esta maa semente dos jmfiees creçeo tamto na horta do Senhor, que sse nom fosse arrimcada pollos fiees e cathollicos primçipes, em breue tempo creçeria tamto, que amortificaria toda a boõa semente". Ibidem, p. 199.
} 
Antes da tomada da cidade pela armada, salientam-se dois episódios de contacto com os mouros dos quais sobressai a sua caracterização: o encontro dos embaixadores do rei de Granada com D. João I na corte portuguesa e o encontro dos navegadores/ conquistadores com os mouros de Algeciras. Nestes episódios, contrasta, em primeiro lugar, a rudeza de D. João I, sempre descrito como homem de temperança, de bondade e pureza, com a modéstia das personagens mouras. De salientar é também o facto de, destes e de outros breves episódios, se evidenciar a caracterização do mouro como potencial traidor e como homem de quem há que desconfiar.

No capítulo trigésimo quarto, antes da chegada dos embaixadores de Granada ao Reino português, o cronista relata a azáfama da preparação das embarcações e a questionação geral da população sobre os motivos para a preparação de tal armada, enfatizando a questionação por parte dos mouros forros que considera como potenciais traidores por serem homens "que nom perderam aquella amizade com todollos outros mouros que a sua seita rrequeria" ${ }^{31}$. Nesta sequência, a fala do rei, no encontro com os embaixadores de Granada, deixa subentendida a suspeição de terem sido os mouros a passar ao Reino vizinho a informação sobre a preparação de uma armada, não havendo outra explicação para a presença dos embaixadores granadinos no Reino. Do episódio do enforcamento do almogávar (no capítulo quinquagésimo sexto) por Pero Fernandez, filho de Martim Fernandez Portocarreiro, subentende-se que a sua morte evita a quebra do secretismo da missão, muito embora nada nos seja narrado a este respeito. A partir dos episódios citados, parece-nos, portanto, lícita a inferência da caracterização do mouro como traidor.

Outra perspectiva negativa sobre o carácter do mouro surge-nos aquando do episódio em que Çalla bem Çalla, inexplicavelmente, manda os mouros forâneos embora e aquando da preparação da defesa da cidade pelos mouros mais jovens. No primeiro episódio, o cronista deixa claro que os mouros não respeitam sequer outros mouros: "ca elles per natureza sam grandes estragadores de cousas alheas" ${ }^{32}$. Por seu turno, no segundo episódio, o cronista ressalta a avareza de alguns velhos que "amdauam

\footnotetext{
${ }^{31}$ Ibidem, p. 106.

${ }^{32}$ Ibidem, p. 176.
} 
escomdemdo seus aueres" ${ }^{33}$ enquanto outros velhos rezam nas mesquitas e os jovens preparavam a defesa da cidade.

\subsection{O mouro: entre a cobardia e a impotência}

Das referências explícitas e implícitas ao mouro, a característica mais evidenciada pelo cronista em diversos momentos ao longo da obra diz respeito à sua cobardia, aos seus pavores e à falsa postura servil. Consequentemente, o cronista apresenta-nos, em diversos episódios, uma pusilânime população moura.

Nos capítulos quinquagésimo quinto e quinquagésimo sexto, à chegada dos portugueses a Algeciras, fecham-se portas e janelas ${ }^{34}$ e encerram-se os jovens mancebos para evitar escaramuças que incitem à ira dos portugueses ${ }^{35}$. O cenário repete-se com a chegada da armada a Málaga: "lançaram toda a frota das naaos caminho de Malega [...] forom em aquelle mesmo dia ante a çidade, onde a toruaçam era antre os mouros por semelhante chegada $[. .$.$] porem fecharom suas portas, e puseromse per çima mais por veer ca por se$ defender"36. E "depois que os mouros virom de todo as gallees ancoradas sobre o seu porto, forom ja algum tanto perdendo de sua primeira segurança" ${ }^{37}$ : instala-se o medo e avisam a restante mourama.

A cobardia do adversário torna-se ainda mais evidente no episódio da luta entre o grotesco mouro nu e Vasco Martins de Albergaria, uma vez que, morto este destemido homem, os demais viram as costas à batalha e recolhem-se na cidade: "E tamto que aquelle mouro foy morto, loguo todollos outros uiraram as costas, e acolheramsse aa çidade" 38 . As palavras de Çalla bem Çalla, mouro nobre mais que os outros segundo o cronista, confirmam a caracterização dos mouros como cobardes porquanto, ao saber da entrada dos portugueses na cidade, incita à fuga em detrimento da manutenção da honra: "pois que a minha maa uemtura e a uossa assy hordena, que ajamos de perder nossa

\footnotetext{
${ }^{33}$ Ibidem, p. 194.

34 "E vos enuiam pedir por merçe, que nam ajaaes por mal de elles mandarem fechar suas portas e poer rrecado em sua villa" Ibidem, p. 166.

35 "a segunda porque alguũs daquelles mouros mançebos nam tenham liure poder pera sair fora da villa. ca poderia seer que se trauaria antre huũs e os outros tal escaramuça, per que vossa merçe aueria alguũa sanha" Ibidem.

${ }^{36}$ Ibidem, p. 169.

${ }^{37}$ Ibidem, p. 169.

${ }^{38}$ Ibidem, p. 204.
} 
homrra e nossas casas e fazemda, trabalhaae por salluardes uossas uidas o melhor que poderdes, porque das rriquezas ja me pareçe que mall uos podees aproveitar" ${ }^{39}$.

A par desta imagem de temeroso e de cobarde, o cronista oferece-nos a imagem de um mouro resignado aos desígnios divinos, ainda que esses desígnios não sejam directamente ditados pelo seu deus. Apesar dos diversos avisos e sinais de que a cidade iria ser tomada, os mouros não agiram em sua defesa. Assim, no capítulo quinquagésimo nono, os mouros que ficaram na cidade reconhecem que, mesmo sabendo da chegada dos portugueses, não fizeram nada para impedir a conquista porque se sentiam "atados":

\begin{abstract}
"verdade he deziam elles, que nos tinhamos esse auisamento. e bem poderamos em treze dias, que elRey andou darredor de nos sem nos fazer nenhum empeçimento, a afortalezar muito mais nossa çidade, e fazer pera nossa guarda mil rremedios se teueramos jndustria, mas as rrodas çelestriaaes nos tinham assi atados, que eramos feitos quasi immouibles. e por tanto nam era em nosso liure poder rreçeber nenhum conselho nem auisamento sobre a cousa determinada" 40 .
\end{abstract}

Naturalmente, apenas explicável por predestinação divina é, segundo o cronista, o facto de Çalla bem Çalla, por requerimento das gentes de Ceuta, ter mandado os mouros de fora da cidade para suas casas, desprotegendo- $\mathrm{a}^{41}$. Não obstante e embora os velhos soubessem que de nada valeria tal esforço, quando os portugueses regressam depois da tempestade, os mouros "nom çessauam de rrepayrar todallas cousas, que semtiam que lhe poderiam prestar pera sua deffemssam. e assy amdauam corremdo per aquelles muros de huũa parte aa outra, mostramdo que nehuũ medo nom auia rrepouso em seus coraçoões" 42 .

\footnotetext{
${ }^{39}$ Ibidem, p. 206.

${ }^{40}$ Ibidem, p. 175.

41 "E mais que tanto que os mouros viram assi partir aquella frota, pensaram que se partira ja de todo [...] porem mandou Çalabençala per rrequerimento dos outros da çidade, que se fossem muito em boõa ora pera suas casas, porque sua presença a elles ja nam era neçessaria" Ibidem, p. 176.

42 Ibidem, pp. 193-194.
} 
Estando os portugueses às portas de Ceuta, o cronista apresenta-nos com mais detalhe o governador da cidade, Çalla bem Çalla, "huũ homem quamto quer de hidade, de linhagem dos Marijs. a qual amtre todallas outras gerações que ssom em Africa, he auida por melhor. e pera elle aimda acreçemtar mais sua nobreza, era senhor daquela çidade e doutros mujtos boõs lugares da costa daquele mar"43, tivera um sonho premonitório da chegada de D. João I e da derrota da cidade às mãos dos cristãos $^{44}$. Perante a inevitabilidade dos destinos de Ceuta e dos seus habitantes, este homem, devoto, dirige-se a Deus e questiona-o, considerando que tal desígnio para a cidade só poderá dever-se a um grave pecado seu. Çalla bem Çalla é-nos apresentado pesaroso e triste ("estamdo assy em este triste cuydado"45) com a constatação do cumprimento da profecia e chora quando recebe a notícia de que os cristãos entraram na cidade ("Çalla bem Çalla uirou o rrostro pera outra parte pera escomder a força das lagrimas, que lhe corriam dos olhos"46).

Os diversos relatos de sonhos premonitórios que os sobreviventes partilham entre si durante o longo lamento pela perda da cidade no capítulo nonagésimo terceiro comprovam, mais uma vez, que os desígnios da cidade estavam previamente traçados e reiteram a impotência dos seus habitantes face aos acontecimentos. Parece-nos, não obstante o cronista procurar transmitir a dor sentida pela facção perdedora, que estes episódios se destinam apenas a corroborar a predestinação da tomada de Ceuta pelos portugueses.

Retrospectivando, no capítulo décimo sexto, do ponto de vista do mouro, a tomada da cidade, o cronista afirma que eles se sentem envergonhados por não terem tido a sagacidade necessária de antever a sua derrocada aquando da visita da embaixada portuguesa e por não terem conseguido defender a sua cidade:

"Alguũs mouros daquella çidade que depois do filhamento della comsijraram sobre a uimda destas gallees, mal diziam a ssy e a fraqueza de seus emtemdimentos, por que tam tarde conheçeram a sagazidade com que

\footnotetext{
${ }^{43}$ Ibidem, p. 197.

${ }^{44}$ Ibidem, cap. LVIII.

${ }^{45}$ Ibidem, p. 198.

${ }^{46}$ Ibidem, p. 206.
} 
sse trautara sua destroiçom. e emtom se acordauam como uiram o prioll hir com sua gallee ao lomgo da çidade assy uagarosamente, como quem sse trabalhaua de a esguardar com fememça"47.

\subsection{A bravura do mouro}

A valentia do mouro é salientada em muito poucos trechos, porém em momentos essenciais da narrativa, os quais permitem particularmente antever a maior bravura dos portugueses. Assim, durante a batalha que os intrépidos Infantes, D. Duarte e D. Henrique, travam com os mouros em terra fica patente a supremacia portuguesa e, em diversos momentos, o cronista salienta o facto de os Infantes vencerem, sem a ajuda de outros soldados, um grupo de mouros.

Antes da entrada na cidade, enquanto os Infantes desarmam vários mouros, surge, de repente, uma singular figura: um mouro nu, com extremada força e cujas armas são apenas pedras. O grotesco mouro, "gramde e crespo todo nuu" que "auia o corpo todo negro assy como huũ coruo, e os demtes muy gramdes e aluos, e os beyços muy grossos e rreuoltos", "uirou o rrostro comtra os christaãos e dobrou o corpo, e foy dar huũa tam gramde pedrada a Vaasco Martimz dAlbergaria sobre o baçinete, que lhe lamçou a cara fora" ${ }^{48}$. O destemido mouro foi, no entanto, e antes que pudesse repetir a proeza, "passado de parte a parte" pela espada do português.

Tal como os episódios de batalha entre os Infantes e os grupos de mouros dentro das muralhas da cidade, a bravura deste mouro serve apenas para demonstrar a valentia dos portugueses, neste caso particular a valentia do próprio Vasco Martins de Albergaria. Não obstante, depois de tomada a cidade pelos portugueses, o cronista salienta a preserverança dos mouros, mas, desta feita, com o intuito de criticar abertamente a "gente do pouoo" que, pela cobiça, não se precata e entra nas casas da cidade com o objectivo de pilhar: "os homeẽs com aquelle açemdimento da cobijça que traziam, emtrauam sem nehuũ rresguardo, e mujtos daquelles mouros jaziam em suas casas mostramdo huũa desauisada perfia, a quall era a morte que poderam escusar"49.

\footnotetext{
${ }^{47}$ Ibidem, pp. 53-54.

${ }^{48}$ Ibidem, p. 204.

${ }^{49}$ Ibidem, p. 213.
} 


\subsection{O mouro: o velho profetizador}

Das referências explícitas ao mouro, salienta-se a imagem do mouro profetizador, um topos também recorrente em diversos textos portugueses e castelhanos e que ainda hoje pulula no imaginário colectivo popular em lendas ${ }^{50}$. Regressado o "priol do Esprital" de Ceuta, onde estivera com o propósito fingido (porquanto a expedição tinha como objectivo único fazer o levantamento de toda a cidade e arredores para a preparação da conquista), de averiguar da possibilidade de uma união entre as Casas Reais, conta uma história da sua infância ao rei, reiterando, desse modo, o sucesso futuro da empresa de conquista da cidade. Aquando de uma viagem com seu pai durante a sua juventude, o prior vai a Ceuta e, depois de deambular pela cidade, junto a um chafariz encontra um velho mouro que o interroga sobre a sua origem. Ao saber que vem do Reino de Portugal, questiona-o sobre a descendência do seu rei e, depois de um detido diálogo, o mouro começa a chorar porque identifica o futuro regente da cidade de Ceuta:

"E amdamdo assy, chegueime a huũa fomte que alli estaua com huũ muy nobre chafariz, homde me eu acostey huũ pedaço tomamdo desemfadamente em ueer a fresmosura dos cauallos que alli traziam a beuer, os quaes eram mujtos e boõs. e estamdo assy sobrechegou hi huũ homem de comprida hidade, cujos auitos e barba eram manifesto sinall de sua uelhiçe. o quall chegamdosse a mim começoume de oolhar pregumtamdome domde era [...]. E eu the rrespomdi como era naturall da çidade de Lixboa [...]. Que aiaaes prazer disse o uelho, dizeeme quamtos filhos baroões tem esse rrey [...]. Empero aa fim ueemdome assy aficado delle, começey de comsijrar com fememça, ataa que me cayo no emtemdimento a uerdadeyra nembramça de uossa naçemça. E emtom lhe disse [...]. Por jsso uos pregumtaua disse elle. e em dizemdo esta pallaura, deu huũ muy gramde sospiro, e abaixou o rrostro assy choranmdo. Da quall cousa eu fui mujto espamtado. e por elle assy comtinuar em seu choro e tristeza, rrogueilhe mujto que me dissesse a causa que o a jsso mouera" ${ }^{51}$.

\footnotetext{
50 ALVES, Carla Carvalho - Figurações do Mouro na Literatura Portuguesa: o lado errado do Marenostrum? São Paulo: Faculdade de Filosofia, Letras e Ciências Humanas, 2010. Tese de Doutoramento.

${ }^{51}$ ZURARA, Gomes Eanes de - Crónica da Tomada de Ceuta..., pp. 56-57.
} 
Neste episódio do capítulo décimo nono da Crónica da Tomada de Ceuta, Zurara reescreve um episódio profético já presente na Crónica lopiana ${ }^{52}$ e transforma Joham da Barroca num mouro, cujas barbas e "avitos" lhe validam a sapiência, ampliando, no entanto, a profecia anterior. D. João será, então, o primeiro rei de Espanha a ter posses em África:

\begin{abstract}
"E como quer que mo per mujtas uezes negasse, aa comclusom aficado de meus rrequerimentos disse. amigo, o meu choro nom he tamto como eu tenho rrezam, nem emtemdas que choro cousa nehuũa que seia presemte, mas pello conhecimento que tenho da perda que a de uijnr a meus naturaaes e amiguos. E porque a tua uemtura te trouue aqui, nota bem o que te agora disser. Sabe que esse Rey Dom Pedro que uos agora teemdes por uosso rrey em esse rregno, nom ha mujto de uiuer, per cuja morte rregnara em su lugar o Iffamte Dom Fernamdo seu primeyro filho [...] E finallmente esse filho pequeno que tu uees menos preçado em comparaçom de seus jrmaãos, sera ajmda em esse rregno como huũa pequena faísca $[. .$.$] e elle sera o primeiro$ rrey dEspanha que teera posse em Africa, e sera o primeiro começo da destruiçom dos mouros. e ajmda elle ou os de sua geeraçom uijram a este chafariz dar de beuer a seus cauallos" 53 .
\end{abstract}

\title{
Nota final
}

Do levantamento da caracterização do mouro, parece inegável que a imagem do outro depende, tal como afirmámos no início desta reflexão, integralmente do "eu" que a descreve e constrói. Sendo a cronística de Zurara um projecto de enaltecimento da Dinastia de Avis e, sobretudo, de exaltação das conquistas em África, parece-nos evidente que todas as descrições do mouro presentes na Crónica da Tomada de Ceuta servem o propósito de encomiar a imagem do eu e de amplificar o seu valor, de modo muito particular a imagem dos Infantes D. Duarte e D. Henrique e, por extensão, dos portugueses que com eles partem para a conquista da cidade.

\footnotetext{
52 Cf. MICHELAN, Kátia Brasilino - Ceuta, para além da terra..., pp. 188-189. Sobre a expressão, em diversos textos portugueses, de uma ideologia messiânica, há vasta bibliografia ao dispor do investigador. ${ }^{53}$ ZURARA, Gomes Eanes de - Crónica da Tomada de Ceuta..., p. 57.
} 
De facto, cremos, a partir dos episódios referidos, que a constante referência ao mouro como infiel pretende justificar a supremacia do catolicismo e a conquista, reiterando que "la définition de l'autre se fonde sur ce qui est considéré comme différence essentielle par rapport à soi [et], pour les portugais, cette différence est en premier lieu de caractère religieux"54. A perspectiva negativa sobre o carácter do mouro permite desculpar a quebra de relações sociais entre mouros e cristãos. As referências à valentia do mouro tornam mais valoroso quem o derrota. As constantes referências à profetização dos factos e à inacção do Deus do adversário reiteram a predestinação dos portugueses.

Em suma e de modo muito generalista, a Crónica da Tomada de Ceuta recupera o topos de descrição do outro com vista ao enaltecimento do eu e o topos de que os portugueses são um povo eleito de Deus, topoi já presentes em diversos textos cronísticos precedentes $^{55}$ e que viria a funcionar como base da identidade nacional e da construção dos mitos messiânicos até ao presente. Consideramos, por fim, que seria interessante analisar, contrastivamente, textos árabes coevos ou posteriores que abordem a conquista da cidade de Ceuta pelos portugueses e verificar qual a imagem do outro e de si próprios neles descrita.

\footnotetext{
${ }^{54}$ BOISVERT, Georges - "La dénomination de l'Autre africain au $\mathrm{XV}^{\mathrm{e}}$ siècle dans les récits des découvertes portugaises". L'Homme [Em linha]. N. 153 (2000), p. 168. [Consultado em 30 Set. 2014]. Disponível em http://lhomme.revues.org/10

${ }^{55}$ Cf. MICHELAN, Kátia Brasilino - Ceuta, para além da terra..., pp.146-204. Por exemplo, na Crónica de D. João I, de Fernão Lopes, a construção da imagem do castelhano como cobarde aquando da Batalha de Aljubarrota serve o propósito do enaltecimento da coragem e bravura dos portugueses, destacando-se o facto de o cronista aduzir que "o poder da Divina Providência [age] em prol dos portugueses como recompensa da sua retidão cristã, expondo que a vitória se deu em grande medida porque eles eram os eleitos de Deus e os verdadeiros fiéis de Cristo" (COSTA, Rodrigo Franco da - "A Batalha de Aljubarrota, um debate sobre a alteridade castelhana a partir do diálogo entre Luís de Camões e Fernão Lopes". Revista Ars Historica [Em linha]. N. 6 (2013), p. 176. [Consultado em 13 Abr. 2014]. Disponível em http://www.ars.historia.ufrj.br/images/6ed/costa\%20rodrigo.\%20ars\%20historica.pdf), porquanto à época dos feitos Castela apoiava o Papa de Avinhão e não o de Roma.
} 


\section{Referências bibliográficas:}

\section{Fontes}

ZURARA, Gomes Eanes de - Crónica da Tomada de Ceuta por el Rei D. João I composta por Gomes Eanes de Zurara. Ed. Francisco Maria Esteves Pereira. Lisboa: Academia das Ciências de Lisboa, 1915.

\section{Estudos}

ALVES, Carla Carvalho - Figurações do Mouro na Literatura Portuguesa: o lado errado do Marenostrum? São Paulo: Faculdade de Filosofia, Letras e Ciências Humanas, 2010 (Tese de Doutoramento).

ANDRADE FILHO, Ruy de Oliveira; CARVALHO, Ligia Cristina - "Medieval Misogyny and its echoes in the Lais of Marie de France", Mirabilia, Bd. 17, pp. 467494.

BARROS, Maria Filomena - Tempos e espaços de mouros. A minoria muçulmana no reino português (séculos XII a XV). Lisboa: FCG/FCT, 2007.

BELLER, Manfred; LEERSSEN, Joep - Imagology: the cultural construction and literary representation of national characters. Amesterdam / New York: Rodopi, 2007.

BERTOLI, André Luís - "Modelos de acção bélica na Crónica de D. Duarte de Meneses. Texto, contexto e representação". Mirabilia [Em linha]. N. 15 (2012), pp. 171-201. [Consultado em 20 Jan. 2015]. Disponível em http://www.revistamirabilia.com/sites/default/files/pdfs/2012_02_09.pdf

BLACKMORE, Josiah - "Imaging de Moor in Medieval Portugal". Diacritics, vol. 36, n. 3/4, 2006, pp. 27-43.

BOISVERT, Georges - "La dénomination de l'Autre africain au $\mathrm{XV}^{\mathrm{e}}$ siècle dans les récits des découvertes portugaises". L'Homme [Em linha]. N. 153 (2000), pp. 165-169. [Consultado em 30 Set. 2014]. Disponível em http://lhomme.revues.org/10 
BRAGA, Isabel M. Ribeiro Mendes - "As relações Mouros / Cristãos nas Crónicas marroquinas de Gomes Eanes de Zurara". Eborensia, n. 19/20 (1997), pp. 171-180.

CARDOSO, Sylnier Moraes - "A oposição mouro-cristão na narrativa de Gomes Eanes de Zurara". in Anais do I Congresso Nacional e II Regional de História da UFG [Em linha]. Jataí, 2008, pp. 1-12. [Consultado em 16 Out. 2014]. Disponível em http://www.congressohistoriajatai.org/2014/anais2008.htm

COSTA, Rodrigo Franco da - "A Batalha de Aljubarrota, um debate sobre a alteridade castelhana a partir do diálogo entre Luís de Camões e Fernão Lopes". Revista Ars Historica [Em linha]. N. 6 (2013), pp. 165-180. [Consultado em 13 Abr. 2014]. Disponível em http://www.ars.historia.ufrj.br/images/6ed/costa\%20rodrigo.\%20ars\%20historica.pdf

DIAS, Isabel Barros - "A migração dos portentos". in VV.AA. - Revisitar o Mito / Myths Revisited. Lisboa: Húmus, 2015, pp. 749-762.

DIAS, Isabel Rosa - "O mouro na Crónica da Conquista do Algarve". in AMADO, Teresa - A guerra antes de 1450. Lisboa: Quimera, 1994, pp. 365-376.

FIGUEIREDO, Albano - "Viagem, cavalaria e conquista na Crónica de Guiné de Gomes Eanes de Zurara". in MIRANDA, José Carlos; LARANINHA, Ana Sofia (org.) - Modelo. Actas do V Colóquio da Secção Portuguesa da Associação Hispânica de Literatura Medieval. Porto: Faculdade de Letras da Universidade do Porto, 2005, pp. 25-33.

FIGUEIREDO, Fernando - "Da imagem do inimigo à construção do herói. O reinado de Afonso Henriques na Crónica dos Cinco Reis de Portugal". in AMADO, Teresa - A guerra antes de 1450. Lisboa: Quimera, 1994, pp. 377-390.

GIMÉNEZ, José Carlos - "As representações dos muçulmanos durante a tomada de Lisboa pelos cristãos". Revista Diálogos Mediterrânicos [Em linha]. N. 7 (2014), pp. 53-65. [Consultado em 5 Jun. 2015]. Disponível em http://www.dialogosmediterranicos.com.br/index.php/RevistaDM/issue/view/13/showToc 
GONZALBES GRAVIOTO, Enrique - "El comes Iulianos (Conde Julián de Ceuta) entre la historia y la literatura". Al Quantir [Em linha]. N. 11 (2011), pp. 3-35. [Consultado em 4 Abr. 2016]. Disponível em http://s17809026.onlinehome-server.info/ojs-2.4.4-1/index.php/alqantir/article/view/185/154

GONZALBES GRAVIOTO, Enrique - "El paso del estrecho: las fuentes". Aljaranda [Em linha]. n. 81 (2011), pp. 37-42. [Consultado em 4 Abr. 2016]. Disponível em http://www.aljaranda.com/index.php/aljaranda/article/view/142

GUIMARÃES, Jerry Santos - "Memória e retórica: mouros e negros na Crónica da Guiné (século XV)". in Anais do XXVI Simpósio Nacional de História - ANPUH [Em linha]. São Paulo, 2011, pp. 1-16. [Consultado em 25 Jun. 2014]. Disponível em http://www.snh2011.anpuh.org/resources/anais/14/1308163586_ARQUIVO_Memoriae Retorica-MouroseNegrosnaCronicadeGuine\%28SeculoXV\%29.pdf

KRUS, Luís - "Tempo de godos e tempo de mouros: as memórias da reconquista". in KRUS, Luís - A construção do passado medieval. Textos inéditos e publicados. Lisboa: IEM, 2011, pp. 93-113.

LOUREIRO, Rui Manuel; CARDOSO, João Passos; CABRITA, Maria da Graça "Visão do mouro nas Crónicas de Zurara". in Caderno Histórico IV. Actas do Seminário "Os Descobrimentos Portugueses e o Algarve d'Aquém e d'Além-Mar". Lagos: Comissão Municipal dos Descobrimentos, 1993, pp. 60-83.

MICHELAN, Kátia Brasilino - Ceuta, para além da terra dos Mouros. A fabricação histórica de um marco do império português (Século XV e início do XVI). Franca: Faculdade de Ciências Humanas e Sociais da Universidade Estadual Paulista Júlio de Mesquita Filho, 2013 (Dissertação de Doutoramento).

MOLL, Nora - "Imágenes del outro". in GNISCI, Armando - Introdución a la literatura comparada. Barcelona: Crítica, 2002, pp. 347-389.

TODOROV, Tzvetan - Nous et les autres. Paris: Seuil, 1989. 


\section{COMO CITAR ESTE ARTIGO}

\section{Referência electrónica:}

PIRES, Natália Albino - “A imagem do outro na Crónica da Tomada de Ceuta pelo Rei D. João I de Gomes Eanes de Zurara”. Medievalista [Em linha]. N. 20, (Julho Dezembro 2016). [Consultado dd.mm.aaaa]. Disponível em http://www2.fcsh.unl.pt/iem/medievalista/MEDIEVALISTA20/pires2007.html ISSN 1646-740X.

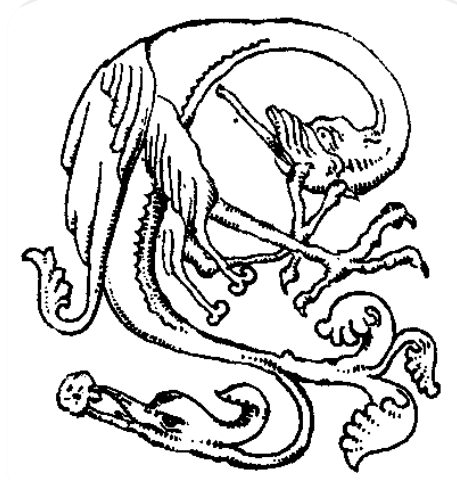

